\title{
The Regional-Matrix Approach to the Training of Highly Qualified Personnel for the Sustainable Development of the Mining Region
}

\author{
Evgeny Zhernov ${ }^{1 *}$, Evgenia Nehoda ${ }^{2}$ \\ ${ }^{1}$ T.F. Gorbachev Kuzbass State Technical University, 650000, 28 Vesennyaya St., Kemerovo, Russia \\ ${ }^{2}$ National Research Tomsk State University, 63405036 Lenina st., Tomsk, Russia
}

\begin{abstract}
The state, regional and industry approaches to the problem of personnel training for building an innovative knowledge economy at all levels that ensures sustainable development of the region are analyzed in the article using the cases of the Kemerovo region and the coal industry. A new regional-matrix approach to the training of highly qualified personnel is proposed, which allows to link the training systems with the regional economic matrix "natural resources - cognitive resources" developed by the author. A special feature of the new approach is the consideration of objective conditions and contradictions of regional systems of personnel training, which have formed as part of economic systems of regions differentiated in the matrix. The methodology of the research is based on the statement about the interconnectivity of general and local knowledge, from which the understanding of the need for a combination of regional, industry and state approaches to personnel training is derived. A new form of representing such a combination is the proposed approach, which is based on matrix analysis. The results of the research can be implemented in the practice of modernization of professional education of workers in the coal industry of the natural resources extractive region.
\end{abstract}

\section{Introduction}

The purpose of the study is to define a modern theoretical approach to the system of training of highly qualified personnel as an important element of the sustainability of the economic systems of the Russian economy at the level of the resource-type region. The scientific novelty of the study is in the application of the regional-matrix approach to the training of highly qualified personnel in the coal industry of the natural resources extractive region, taking into account the features of the modern innovative stage of economic development. The scientific significance is in identification and systematization of the theoretical (conceptual) approaches to the system of training of highly qualified personnel as illustrated by the Kemerovo region - an important mining region in Western Siberia.

The practical significance of the study is related to the possibilities to use the proposed regional-matrix approach for justification, formulation and adoption of solutions on strate-

\footnotetext{
" Corresponding author: zhee.eti@kuzstu.ru
} 
gic issues of sustainable development of the system of training of highly qualified personnel in the natural resources extractive regions of the Russian Federation. This goal is achieved by means of scientific substantiation of the necessity, opportunity and feasibility of linking the systems of training of highly qualified personnel with the regional economic matrix previously developed by the author (in co-authorship), into which they fit as parts of the economic systems distributed across the quadrants in the coordinates of natural resources - cognitive resources.

The relationship of this study with the previously published works. The existing approaches to personnel training, which seem relevant to the research topic, can be conditionally divided into three groups. The first group, a nationwide (state) approach in a program form, first of all concerns the development of federal educational and professional training standards. The second group is an industry approach, which today expresses mainly the private interests of owners of privatized primary commodity companies. The third group is a regional approach designed to integrate the interests of local authorities and the local community. Let us briefly characterize these approaches.

The state approach. Training of qualified personnel for high-tech industries and the primary sector of the economy as an indispensable condition for the successful innovative development of the knowledge economy is the most important task of the state. The relationship between the quality of public administration and innovations in the regions (in the European case) was investigated in [1]. It is necessary to recognize the opinion of experts that in the modern world the quality of the functioning of the national education system of a particular state can be regarded as a strategic state resource (in analogy with strategic resources of fresh water, energy resources, etc.). In accordance with the Strategy for Scientific and Technological Development of the Russian Federation until 2035 (hereinafter referred to as Strategy 2035), at the first stage (2017-2019) an integral system of sustainable reproduction and recruitment of personnel is being formed. Strategy 2035 is the basis for the development of state programs of the Russian Federation, state programs of its regions, industry documents of strategic planning in the field of scientific and technological development of the country, as well as planning and program-target documents of state corporations, state companies and joint-stock companies with state participation. In doing so one can take into account, for example, the English experience of integrating sustainable development in planning at the regional level described in [2].

In accordance with the Russian official document among the priorities and prospects for scientific and technological development of the country there is an increase in the efficiency of extraction and deep processing of hydrocarbon raw materials. Hence the need to train specialists in this field, and the Federal State Educational Standard of General Education, developed by the Ministry of Education and Science of Russia, should be coordinated with Strategy 2035 and the Program for the Development of the Coal Industry of Russia for the period up to 2030 (hereinafter referred to as Program 2030). In the latter official document, the interests of the state, regions, professional educational organizations, educational organizations of higher education, specialized scientific organizations and owners of enterprises in the process of improving vocational education are interlinked on the basis of federal state educational standards. Thus, the state program approach has been implemented to the coal industry located on the territory of a number of regions of the country, including the Kemerovo Region.

The industry approach presupposes the formation of an industry-specific training system, which includes state-private partnerships in education and science, vertically and horizontally integrated corporate university complexes, basic departments and laboratories. This approach reorients the centralized financing of education and science "in general" to support specific scientific and educational complexes and projects of the real sector of the economy. For example, the role of small firms in the presence of large laboratories in re- 
gions with sustainable innovative development is disclosed in [3]. Industry university complexes are designed to become points of growth in the country's economy based on new innovative principles of development. Recommendations for the training, professional retraining and advanced training of engineering and technical personnel for mining enterprises in accordance with the Concept of Improving the System of Training, Professional Retraining and Professional Development of Personnel for Coal Industry Organizations are given by Russian specialists. Among the most significant problems in the development of human resources are the lacks of industry-wide professional standards recognized at the national and international levels.

The regional approach. Scientists note the regionalization of the training of highly qualified personnel as a trend in the formation of the knowledge economy. A normative legal instrument that is able to ensure the unity of requirements in the professional sphere and to create conditions for professional growth of personnel, taking into account the state requirements for the education system at the federal and regional levels, is a professional standard. The regional component of the professional standard is based on the requirements for personnel taking into account the local socio-cultural, socio-economic and historical features of the development of the region.

The proposed regional-matrix approach to the training of personnel develops such paradigms of the region as the region-quasi-corporation and the region-society. Representation of the region as a quasi-corporation allows researchers to use economic categories for analysis. In this capacity, regions are considered as subjects of economic activity competing with other regions-corporations in the market of educational services. The approach to the region as a society - the community of people living in a certain territory - actualizes the issues of the reproduction of social life. Therefore, the paradigm of the "region-society", on the one hand, is more general than the economic one, on the other hand, requires the consideration of more factors, which complicates its application. The consideration should include not only educational, but also cultural, medical, socio-psychological, political and other aspects of the life of the population of the region. The studies $[4,5]$ show that, without the growth of human capital, sustainable economic growth in the region is not possible, moreover, the former generates the latter. This fact is taken into account by the proposed matrix: the separation and analysis of the mutual positions of the regions in the matrix are conducted by an integral set of criteria for the knowledge economy. The comparison of existing and proposed approaches in essence, which, we believe, is in the quality of training, is presented in Table 1.

Table 1. The comparison of existing and proposed approaches to personnel training.

\begin{tabular}{|l|l|}
\hline \multicolumn{1}{|c|}{ An approach } & \multicolumn{1}{c|}{ The essence of the approach } \\
\hline State (federal) & $\begin{array}{l}\text { The quality of training is determined by the degree of compliance } \\
\text { with state standards }\end{array}$ \\
\hline Industry & $\begin{array}{l}\text { Criteria for the quality of training are specific to each industry, fo- } \\
\text { cused on preserving the best industry traditions in the field of train- } \\
\text { ing of highly qualified personnel }\end{array}$ \\
\hline Regional & $\begin{array}{l}\text { The quality of training is determined by the degree of compliance } \\
\text { with the set of requirements developed by administrative structures } \\
\text { that exercise control in the regional education }\end{array}$ \\
\hline $\begin{array}{l}\text { Regional- } \\
\text { Matrix }\end{array}$ & $\begin{array}{l}\text { The quality of training is determined by the degree of satisfaction of } \\
\text { consumers, expressed in market categories of profitability of the } \\
\text { educational organization and profitability for the consumer due to } \\
\text { the constant improvement of all components of the vocational edu- } \\
\text { cation process }\end{array}$ \\
\hline
\end{tabular}


Thus, the shortcomings of existing approaches have been identified and a new approach, favoring the sustainable development of the region, has been proposed, which is based on the dependence of the analyzed process on the specifics of the regional economy.

Theoretical foundations of the regional-matrix approach. An important factor in the modern training of highly qualified personnel, advanced training and retraining of specialists for mining and processing of solid minerals is their implementation in the conditions of the formation of a new economy. The use of the system of recurrent training and retraining of highly-demanded and highly-qualified personnel within the innovation cycle is the basis for the formation of a sustainably developing "new economy" or "knowledge-based economy". According to Nigerian scientists [6], knowledge economy is a "panacea" for sustainable development. The principles of re-education and retraining of professional personnel for the sustainable development of the economic systems of the regions are: 1) focus on the advanced areas of work; 2) consideration of the available educational potential and maintenance of continuity of training; 3) flexibility of forms of advanced training; 4) the advanced nature of teaching new progressive technologies; 5) optimization of costs for professional training and retraining through multi-channel financing.

The proposed economic matrix of the regions makes it possible to identify the distinctive features of the formation of a new knowledge economy at the mesolevel and to reveal the originality of this process in the mining region. We place Kemerovo Oblast as a typical mining region in the "natural wealth" quadrant of the proposed matrix. It characterizes the raw material economy of the region with abundant natural resources and with cognitive resources below the national average. Such an economic system is characterized by a narrow specialization based on the exploitation of non-renewable natural resources, the predominance of the raw-material orientation of the industrial-type economy. It has a high labour intensity of production with a relatively lower level of equipment and technology, limited investment in the development of the potential of an employee. As a result, human development indicators in the region, including the level of training, are below the national average. To ensure sustainable development of the region and its transition to the "harmonious wealth" quadrant, representing the knowledge economy in the natural resources extractive region, it is extremely necessary to improve the quality of training of innovative personnel in the leading sectors of the region.

For the methodological basis of our study, we adopted the UNESCO experts' statement that in modern conditions an important role plays local knowledge about the methods of using resources and social interactions that are the basis for sustainable development at the local level [7]. At the same time, Russian scientists rightly point out that along with local knowledge and skills there are also general universal knowledge and skills that are necessary for the development of natural resources. It is from the statement about the interconnectedness of general and local (industry, regional) knowledge follows, in our opinion, the understanding of the need for a combination of regional, industry and state approaches to training of personnel. Next, one should choose the form of representation of such a combination. A required new form is the proposed approach, based on matrix analysis. In the case of natural objects, location and geographical space are indeed key factors in explaining cognitive factors (knowledge, innovation). The proposed economic matrix of the regions shows this point clearly. Therefore, in order to analyze and evaluate the role of the processes of creating and disseminating professional knowledge in a particular industry (the coal industry in our case), we need to take into account the spatial (regional) features of these processes. The identification of spatial dependence in the analysis of regional economic development is presented in [8]. The same goes for firms, because they are located in a certain territory, where local knowledge is in demand above all. It is natural to assume that this knowledge is created and spread in the same place. Consequently, the role and place of the 
carriers of local knowledge transferred in the personnel training vary depending on the type of region (according to the matrix).

Thus, the proposed regional-matrix approach unites three approaches - state, industry and regional, those are implemented in a complex manner in separate territories of a single country.

\section{Results and Discussion}

The result of this study is the understanding that for sustainable development it is necessary to take into account the state, industry and regional interests in the training of personnel on the ground and to transfer knowledge of all levels, with the domination (d) of interests and knowledge of the corresponding system level (Table 2).

Table 2. Domination of types of interests and knowledge at a certain level of training of highly qualified personnel in the knowledge economy.

\begin{tabular}{|l|c|c|c|}
\hline \multirow{2}{*}{$\begin{array}{c}\text { Interests and } \\
\text { knowledge }\end{array}$} & \multicolumn{3}{|c|}{ System levels } \\
\cline { 2 - 4 } & state (federal) & $\begin{array}{c}\text { industry, including } \\
\text { intrafirm }\end{array}$ & regional \\
\hline 1. Interests & $\mathrm{d}$ & $\mathrm{d}$ & $\mathrm{d}$ \\
\hline 1.1. Common & \multicolumn{3}{|c|}{$\mathrm{d}$} \\
\hline 1.2. Private & $\mathrm{d}$ & $\mathrm{d}$ & $\mathrm{d}$ \\
\hline 2. Knowledge & $\mathrm{d}$ & $\mathrm{d}$ \\
\hline 2.1. General & \multicolumn{3}{|c|}{} \\
\hline 2.2. Local & &
\end{tabular}

This understanding is possible on the basis of the matrix, which determines the essence of the proposed regional-matrix approach to personnel training. The state-private and statepublic partnerships in the field of personnel training based on the economic policy of transferring general and local knowledge and technologies to the industry of the region are the modern forms of the synthesis under consideration. This trend is typical for OECD countries [9].

The following propositions are the most important moments for organizing the regionalmatrix training of specialists of the Russian Federation as illustrated by the natural resources extractive region. 1 . The specific nature of the extractive region of the country in terms of natural and cognitive resources makes special demands on the training system. Among its most important elements, in addition to professional knowledge, are compulsory practices at local unique enterprises, the ability to act in extreme (emergency) situations, to comply with the rules of using regular means of self-salvage in accordance with international requirements. On the skills for sustainable development and the corresponding transformation of vocational education, see [10]. 2. The development of a scientific and innovative environment in regional universities, which is part of the "know-how carousel" or "know-how hub" [11], reflecting the current level of the world's coal mining machine building and fuel-energy complex, which allows to train personnel in Russia that meet the requirements of the world's leading power. Higher education, forming the intellectual community of the regions of the country, should not only revive the best domestic traditions of training of mining engineers, but also should become one of the attractive sides of Russia regarding the export of education. 3. Development of the educational system for the mining equipment industry and accelerated modernization of the technological base of the coal industry, development of new technologies for extraction, processing and supply to the domestic and world markets of coal products should proceed synchronously. This will generate a synergistic effect of the development of the interconnected industries of the region. 4. 
Future development of large multi-level university complexes that unite technical higher and secondary educational institutions, small enterprises at universities, basic departments and laboratories at the leading enterprises of the region; development of multi- and singleindustry colleges for the training of highly skilled workers. Such complexes are a source of general and local knowledge for local enterprises [12]. 5. Personnel policy, according to the regional-matrix approach, ensures the selection of personnel on the basis of professionalism and the conformity of education to the profile of the industry (agency), taking into account regional specifics. Without a radical restructuring of the training system, the economic systems of the regions of Russia will not be able to develop sustainably and to solve the socioeconomic tasks entrusted to them by society.

\section{Conclusion}

This study has defined the basic theoretical propositions of implementation of the regionalmatrix approach to the training of highly qualified personnel in the coal industry of the mining region of the Russian economy, taking into account the specifics and requirements of the modern innovative stage of sustainable economic development. These propositions, in our opinion, can be taken as a basis for justifying the system of training of innovative personnel of industrial enterprises in the mining region for its sustainable development. The training segment is the foundation for the formation and development of all spheres of the knowledge-based society, including the knowledge economy. Therefore, the sustainable development of the region as an economic entity of the new economy depends on the quality of personnel training. It is proved that the new system of training of highly qualified personnel of the leading coal-mining complex in Western Siberia can and should become an impetus to accelerate the innovative development of its economic system. The proposed development of the modern regional-matrix system of personnel training in the context of the knowledge economy of the leading industries of the region is based on a comprehensive approach to the modern organization of the educational process. It includes the establishment of vertically and horizontally integrated university complexes, state-private and statepublic partnerships in science and education. It will ensure the targeted training of innovative personnel, demanded by the leading sectors of the economy of the mining region for its sustainable development.

\section{References}

1. A. Rodriguez-Pose, M. Di Cataldo, Journal of Economic Geography, 15, 673 (2015)

2. D. Counsell, G. Haughton, Geoforum, 37, 6, 921 (2006)

3. A. Agrawal, I. Cockburn, A. Galasso, A. Oettl, J. of Urban Economics, 81, 149 (2014)

4. A.A. Batabyal, P. Nijkamp, J. of Evolutionary Economics, 23, 909 (2013)

5. A. Barnir, Management Decision, 50, 399 (2012)

6. A. Ogundeinde, O. Ejohwomu, Procedia Engineering, 145, 790 (2016)

7. What is Local and Indigenous Knowledge? United Nations Educational, Scientific, and Cultural Organization, (Washington, UNESCO, 2017)

8. M.B. Pietrzak, J. Wilk, T. Kossowski, R. Bivand, Proceedings of the 8th Professor Aleksander Zelias International Conference on Modelling and Forecasting of SocioEconomic Phenomena, 135 (2014)

9. OECD Science, Technology and Industry Scoreboard 2015: Science and Research Today, (2015) 
10. S. McGrath, L. Powell, International J. of Educational Development, 50, 12 (2016)

11. J.G. Wissema, Towards the Third Generation University: Managing the University in Transition (2009)

12. H. Pinto, M. Fernandez-Esquinas, E. Uyarra, Regional Studies, 49, 1873 (2015) 
